\title{
Family Policy in Western Europe
}

\author{
JOUKO HULKKO \\ Managing Director \\ The Finnish Population \\ and Family Welfare Federation
}

\section{Introduction}

Fertility has been below replacement level for a long time in most European states. This has resulted in the retardation of population growth and the aging of the population structure. The decrease of population and intense aging of the age structure are to be expected, especially as life expectancy has increased. These aspects have an impact on the welfare of the individual and on the functioning of society.

There have also been noticeable changes in the structure of families in Europe during the last $20-30$ years. The proportion of nuclear families - a couple and their dependent children - has declined and the proportion of one-parent families and consensual unions among all families with children has increased. The largest proportion of single providers have been divorced or widowed and the majority of them are mothers. Single providers have less children on the average than two-parent families (Ermisch 1987; Kamerman and Kahn 1989)

The intention of this survey is to give an up-to-date cross section of the family policies in West European states and to examine whether the family policies have points in common with possible population policy aims. ${ }^{1}$

The central aim of family policy is to offer families with children and other members of society social justice by providing the families with adequate economic and functional possibilities to carry out their tasks. Other important goals are the realization of the equality between the sexes in family and guaranteeing all children equal childhood conditions. Parents should be guaranteed the freedom of choice over different alternatives, as well as the right to choose how they would like to spend their lives in their pluralistic society.

Housing policy, health policy, educational policy and regional policy all contribute to family formation and fertility. There are also other factors (local authorities, corporations, labor market organizations and the mass media) in society which create the external circumstances and values which can affect people having children and the number of children in families. These measures and factors are not included in the survey.

In order to be able to compare the same time or period accurately, all information and data on the tables are from January 1, 1988, if not otherwise mentioned.

\footnotetext{
1 The data used in this article are based on an unpublished report by Council of Europe, 1989.
} 


\section{Overview on existing family policy measures}

\section{Working life ${ }^{2}$}

The participation of women in the labor force has increased particularly rapidly in all states except those of Southern Europe during the last two decades (Figure 1). Women are now working in almost every occupation and at all levels, but a high proportion of them are still concentrated in a few traditionally female jobs. The average hourly earnings of women are still substantially lower than the earnings of men. However, this gap has narrowed considerably. Nevertheless, there has been no marked change in the sharing of responsibilities between men and women, since women continue to work outside the home and to perform household tasks as well.

In the Nordic countries, female labor force participation rates are now almost the same as those of men. The lowest participation rates are in Southern Europe (excluding Portugal), Ireland and the Netherlands.

In all states, women's participation in the labor market has had important effects on the pattern of activity of women over the life-cycle and especially on family life. Also, the patterns of participation rates by age have changed and the diversity between states is considerable. The data for the most recent age cohorts for France, Finland, Norway and Sweden are consistent, with no sign of a substantial net withdrawal of women from the labor market during the peak childbearing years. On the other hand cohort patterns of Germany, Ireland and the United Kingdom indicate the withdrawal of a significant proportion of young women.

The analysis available for selected cohorts in the Federal Republic of Germany and the United Kingdom indicate that part of the overall increase in women's participation rates in the labor force can be accounted for by the improved educational attainments from generation to generation.

Many factors, economic, educational and social, lie behind changes in female labor force participation rates. Rapid transformation in the numbers and types of jobs offered, generally slackening economic growth and declining fertility are relevant, characteristic features of this period. In general the age span of childbearing has narrowed, which facilitates women's labor force participation.

\section{The length and time of working hours}

Working hours have been shortened in the European states for quite a long time. The most common working hours are 40 hours per week and 8 hours per day (Table 1, see p. 18). Besides common laws on working hours there are special laws and collective labor agreements, according to which working hours can be shorter or longer than those prescribed by law.

A five-day working week is now common in all states. In some states weekly working hours remain below 40 hours. In several states legislation does not limit shift work, but collective labor agreements might do so in some states, for example up to 120 hours in three weeks or up to 80 hours in two weeks. All states have provisions restricting recourse to night shift work without distinction of sex. In nine states there are limitations for women's night work. However, there are numerous exceptions to the rule for different reasons, particularly for young workers, pregnant women and in the case of unhealthy work.

2 This section is mainly based on the OECD Employment outlook: September 1988. 
Figure 1.

FEMALE PARTICIPATION RATES 1967 - $1987^{\circ}$

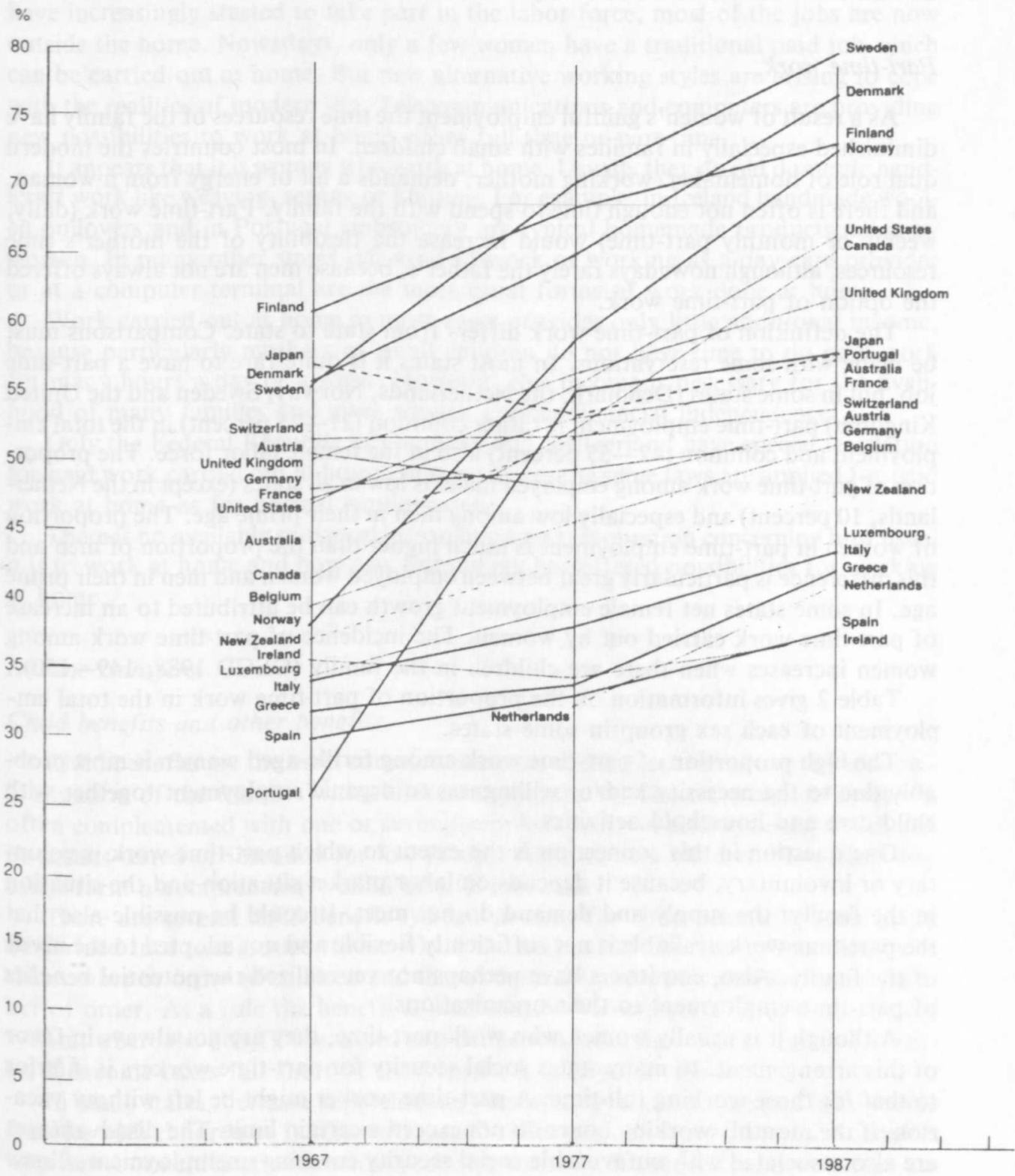

Source: OECD Employment Outlook, September 1988. 
The structural changes in societies, occupation mix and the expansion of the service sector have significantly increased the participation of women of fertile age (aged $20-44)$ into the labor force (OECD 1988). This and various family requirements could be the reason that during recent years attention has been paid to flexible working hours, because this would be a help in arranging small children's day care. The system of flexible working hours is widespread in the Federal Republic of Germany, Sweden and Switzerland. Usually the daily working hours can be flexible, but in Italy, for example the length of a working day may vary in accordance with the yearly variation of production. This does not take family's conditions into account, but instead the variation is based solely on industrial production.

\section{Part-time work}

As a result of women's gainful employment the time resources of the family have diminished especially in families with small children. In most countries the modern dual role of homemaker/working mother, demands a lot of energy from a woman, and there is often not enough time to spend with the family. Part-time work (daily, weekly or monthly part-time) would increase the flexibility of the mother's time resources, although nowadays rarely the father's, because men are not always offered the option of part-time work.

The definition of part-time work differs from state to state. Comparisons must be made with some reservations. In most states it is quite rare to have a part-time job, but in some states (Denmark, the Netherlands, Norway, Sweden and the United Kingdom) part-time employment is rather common $(21-25$ percent) in the total employment and common ( $42-55$ percent) also in the female labor force. The proportion of part-time work among employed males is low in all states (except in the Netherlands, 10 percent) and especially low among men in their prime age. The proportion of women in part-time employment is much higher than the proportion of men and this difference is particularly great between employed women and men in their prime age. In some states net female employment growth can be attributed to an increase of part-time work carried out by,women. The incidence of part-time work among women increases when there are children in the family (OECD 1988, 149-150).

Table 2 gives information on the proportion of part-time work in the total employment of each sex group in some states.

The high proportion of part-time work among fertile-aged women is most probably due to the necessity and/or willingness to organic employment together with child care and household activities.

One question in this connection is the extent to which part-time work is voluntary or involuntary, because it depends on labor market situation and the situation in the family: the supply and demand do not meet. It could be possible also that the part-time work available is not sufficiently flexible and not adopted to the needs of the family. Also, employers have perhaps not yet realized the potential benefits of part-time employment to their organizations.

Although it is usually women who work part-time, they are not always in favor of this arrangement. In many states social security for part-time workers is inferior to that for those working full-time. A part-time worker might be left without vacation, if the monthly working hours do not exceed a certain limit. The disadvantages are also associated with unfavorable social security covering unemployment, illness and retirement.

In the Federal Republic of Germany and in Switzerland a part-time worker must be treated by the employer like a full-time worker. The part-time worker is entitled 
to a normal vacation and in case of illness he or she is entitled to a normal salary.

In some states it is typical to have part-time work in addition to full-time work. In several states the part-time work of school children and students is common as is peak-hour employment.

\section{Paid work carried out at home}

In agrarian societies women worked with men as assisting members of the family. Primarily they worked on their own farms. During the last few decades as women have increasingly started to take part in the labor force, most of the jobs are now outside the home. Nowadays, only a few women have a traditional paid job which can be carried out at home. But new alternative working styles are arising to cope with the realities of modern life. Telecommunications and computers are providing new possibilities to work at home either full-time or part-time.

It appears that it is women who work at home. Usually they do old domestic handicraft work like weaving, sewing or knitting. For example, in Iceland handmade woolen pullovers and in Portugal embroidery are typical homemade products made by women. In many other states this kind of work or working as a day-care provider or at a computer terminal are the most usual forms of work done at home.

Work carried out at home in most cases provides only little additional income, because particularly mothers of small children do not have time to do paid work for many hours a day or a week. However, this income is necessary for the livelihood of many families and gives women greater financial independence.

Only the Federal Republic of Germany and Switzerland have special legislation for paid work carried out at home. In some states the same laws are applied for paid work at home as for normal employment.

There is no available statistical information on this question concerning how usual it is to work at home and how new technology has offered possibilities for working at home.

\section{Income transfers}

\section{Child benefits and other benefits}

Child benefits are the most common measure of support to improve the economic situation of the families with children (Appendix 1). The child benefit system is often complemented with one or several supplementary benefit systems, which can be means-tested or intended for low-income families with children. Together they often form a comprehensive child benefit universe.

There are several child benefit systems in use. The child benefit systems could be divided into two groups, those where the amount of the benefit increases with the number or order of children and those where the amount is irrespective of number of order. As a rule the benefit is paid in money. An exception is the Icelandic system, where the benefit is granted as a deduction from state income taxes. However, if income taxes fall short of the benefit, it is payable directly.

In many states there are supplementary benefits, granted to large or low-income families with children or families with small children (for benefits for which families with new-born children are entitled, see Appendix 1). If supplementary benefits are included in the child benefit system, graded benefit systems are the most common. There are only a few states where it is not graded (Denmark and the United Kingdom). 
In most states the child benefit system is a unitary system which is valid for all families in the country. In some states, especially those where the child benefit system was instituted first among wage earners in industry and commerce, i.e. Belgium, Italy, Switzerland, there are still several systems in use. In Italy and Switzerland the child benefit is granted to employees and farmers. In Switzerland the benefit systems vary from canton to canton.

The scale of grading varies from state to state. In many states the amount increases from the first to the fourth or fifth child and remains unchanged for the following children. However, there are many exceptions. In the Netherlands the benefit grows until the twentieth child. In Sweden the child benefit is the same for the first two children and a supplementary benefit is paid to families with three or more children. In Ireland the benefit is the same for the first five children. In Malta it is degressive, because the population density is considered to be very high. In Cyprus only families with four or more children are entitled to child benefit.

In a few states the child benefit is also graded according to age. In France a supplement is paid for children aged 10 and 15 , in Iceland the corresponding age is 7 , in Liechtenstein 10, in Luxembourg 6 and 12 and in the Netherlands 5 and 12. In Finland a supplementary benefit is paid for children under three years of age.

Means-tested child benefits are unusual. In Greece the recipients of child benefits are divided in four income groups. In the Federal Republic of Germany the child benefit for high-income families is reduced for the second and subsequent children. In Portugal child benefits are aimed at low income families.

The supplementary benefit is often intended for families with a small income and is means-tested. This is the case in France, Iceland and Italy.

France has developed a unique supplementary benefit system. A means-tested benefit is paid to families with three or more children aged three or more. Even if it is means-tested, nine out of ten families with three or more children receive this benefit. Low-income families with school-aged children are entitled to a school-expense benefit. A housing benefit is graded not only according to income but also according to the number of children and housing costs. A special benefit is designed to provide financial assistance to working parents or to single working parents employing a person to care for their child or children under three years of age in their home.

Child benefits are usually granted for children up to $16-18$ years. In many states the age limit is extended to $20-25$ years of age, if the child is handicapped or being educated. Other reasons may also entitle persons to an extended benefit. Such are, for example, unemployment, military service, work as help in the household of their parents or of the beneficiary. In some states special benefits are paid for handicapped children.

In many states special benefits in addition to child benefits are granted to oneparent families.

A special kind of benefit is the housing benefit or subsidies granted in some states. Besides France, families with children in the Federal Republic of Germany are entitled to a housing benefit graded according to income, number of children and housing costs. In Finland and Sweden, a housing subsidy is paid to low-income families. In Sweden one-third of all families with children receive a housing subsidy, which consequently forms an important part of measures aimed to support families with children. The Finnish housing subsidy is mainly focused on the lowest income groups.

From the information available, it is not possible to determine the share of child benefits in the economic position of families with children or how much benefits cover the consumption expenses of the child. 
Table 3 gives some kind of a picture of the economic significance of child benefits in a working family with two children. In four states the proportion is about 10 percent or higher, mostly approximately $5-8$ percent of the average monthly wage in manufacturing. The comparison should, however, be regarded with certain reservations.

\section{Tax deductions}

Tax deductions form a part of the income transfers to families with children. Child deduction is given in 16 states, in 8 of which the amount of the deduction has been graded upwards as the amount or age of the children increases. In the rest of the states the child deduction is the same size for all children or there are conditions under which it is granted, for example, for schooling the child (see Appendix 2).

France has its own system according to which income liable to taxation is divided into shares. Each parent has a share and, each child half a share. The progressive income tax is calculated according to more favorable rates for a lower income level. Denmark, Liechtenstein, the Netherlands, Turkey and the United Kingdom have no special tax deduction for children.

Families are also given housing support. In 12 states the housing loan interests are deductible and, in some states, also part of the construction expenses and installments on the loan. The amount of these deductions is usually limited.

The education expenses for children are deductible in 11 states. The amount of the deduction depends on the educational institutions and it is normally bigger in institutions for higher education. Child-care costs are deducticle with some restrictions in 9 states. In 12 states single supporters get a special extra deduction. Maintenance benefit may be deducted in 6 states. In some states a special deduction can be made if the child is handicapped or doing his military service. The age of the child from whom a tax deduction can be made varies between states, and even within states depending on the grounds for the deduction.

On the basis of available information, it is difficult to evaluate the economic significance of tax deductions to families with children. They complement the entity formed by child benefits and other income transfers and they can even be considerable, for example, due to the tax deduction right concerning housing loan interests. The differences in the taxation systems also makes the comparison difficult.

Tax deductions still have a role in European family policy, although they have their weaknesses. Income deductions are pecuniarily more favorable to those with high income than to those with low income. Tax deductions treat all taxpayers equally, but those who have income liable to taxation are left outside the system. In most of the states there is an ongoing debate on the neutrality of tax measures concerning married or unmarried couples with or without children.

To get a general picture about the value and importance of child benefits and the other benefits, tax deductions and free services, an illustrated description could be a useful method when promoting the well-being of families with children. Figure 2 is a kind of description of the family's proportion of the consumption costs of the child. Figure 3 shows the difference between the disposable annual income per consumer unit in families with two children and in families with no children. The examples are from Finland. 
Figure 2. The total consumption expenses of the child in Finland in 1987, the family's own proportion of consumption costs, allowances, tax deductions and the value of free services.

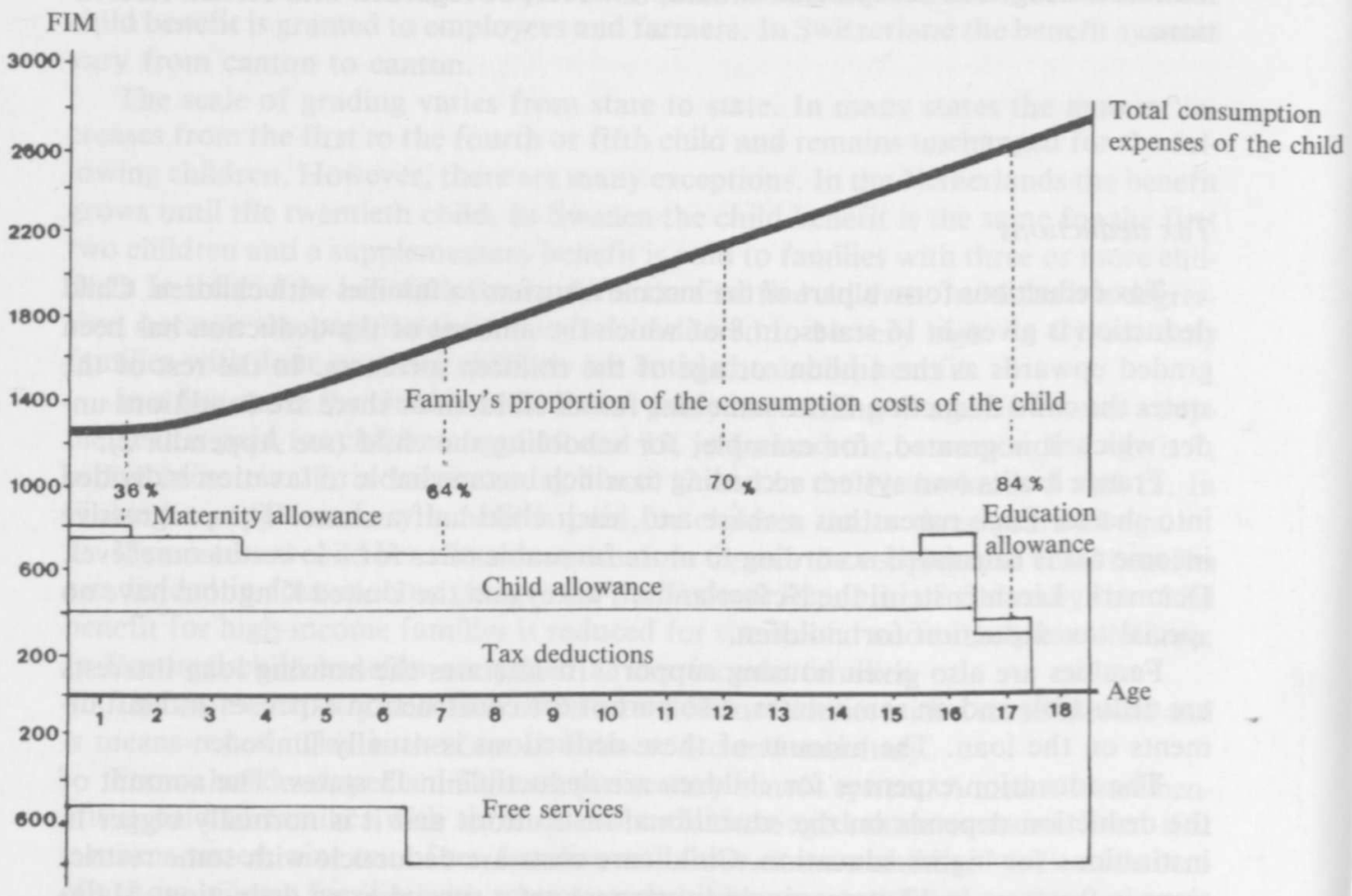

The consumption expenses are based on the average expenses of a 7-year-old child. The expenses are estimated to grow linearily from two to 16 years. At the age of two it is 70 percent of the average expenses and at the age of 1650 percent more than average. The costs, tax deductions and values of free services are estimated from statistics and consumption surveys.

\section{Child-care leaves}

Maternity benefit, maternity leave, counseling

Maternity welfare has improved in all of Western Europe during the last decade. Some states have special regulations concerning the participation of pregnant women in work. In the replies of Belgium, Cyprus, the Federal Republic of Germany, Liechtenstein, Sweden and Turkey, it was mentioned that there are regulations regarding pregnant women working, for example in physically strenuous jobs and jobs including a health risk. In addition, in Cyprus, the Federal Republic of Germany, France, the Netherlands, Switzerland and Turkey mothers taking care of an breastfeeding their babies have an opportunity to take a break during the working day. In eleven states special benefits are paid at birth and during the children's first years (see Table 4).

In order to protect the health of the mother and the new-born child, pregnancy leave or/and maternity leave has been introduced in all states (see Table 5). The length of the leave varies from state to state. Even if there seem to be almost as many different systems and concepts concerning leaves as there are states, some similarities could be found in states which are culturally or linguistically related or have the same historical background. 
Not all mothers are entitled to maternity leave and benefit. In states where the benefit is based more or less on a pure insurance system - almost half of all states - only gainfully employed mothers have the right to maternity leave and benefit.

In most states the pregnancy leave is $12-14$ weeks. Only one state has a shorter leave. Austrian, Finnish and Swedish mothers have the longest leave. It should be mentioned that the length of the leave shown in Table 1 is the minimum length stated by law. In many states agreements between labor market organizations would presume a longer leave than that enacted by law.

Figure 3. The disposable annual income of childless couples and families with two children on different income stages in Finland. Both spouses are employed.

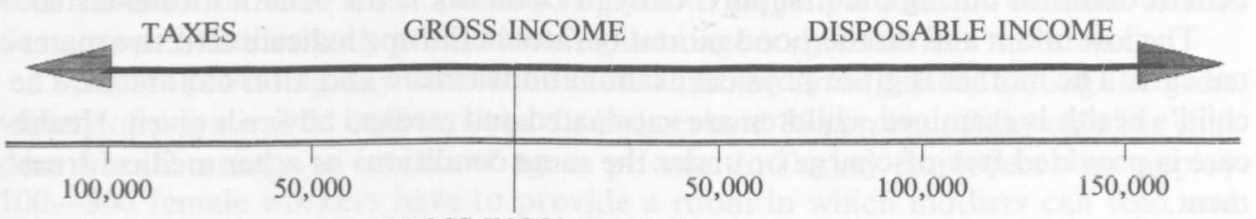

GROSS INCOME 236,000

\begin{tabular}{|l|l|l|}
\hline $87,750=37,2 \%$ & Two adults \\
\hline $79,910=33,9 \%$ & 148,250 & $\begin{array}{l}\text { Two adults, } \\
\text { two children }\end{array}$ \\
\hline
\end{tabular}

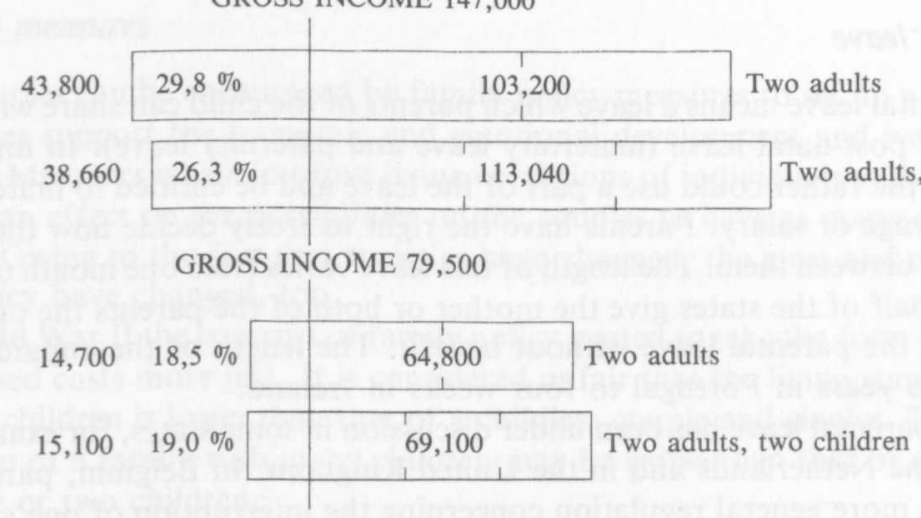

Source: Central Statistical Office of Finland, Statistics of income and property in 1987 (preliminary data).

1 adult $=1$ consumer unit

2 children $=1$ consumer unit

The difference between the disposable income per consumer unit per year (i.e. in favor of the childless couples):

Gross income The difference per year

$236000 \quad 20530$

$147000 \quad 13930$

$79500 \quad 9370$ 
In all states the leave could be started before the expected birth. Contrary to the post-confinement leave, which mostly is more or less obligatory, part of the leave prior to confinement mostly signifies a right to interrupt work. Only a couple of states have no regulations concerning the leave before the estimated date of birth. The right to the leave varies from a couple of days in Malta to almost nine weeks in Greece, Italy, Liechtenstein, Luxembourg, Norway and Sweden and eleven weeks in the United Kingdom.

In almost all states the mother has the right to a maternity benefit during the leave, or at least part of it (Table 6). Several systems could be used simultaneously. In a few states the employer pays full wage or salary during the leave but mostly the benefit is part of an insurance system or social security. Those who do not receive their full wage or salary during the leave are entitled to a maternity benefit. In most states the size of the benefit normally is between 100 and 80 percent of the mother's normal earnings. Often the benefit is higher in the beginning of the leave. During the last part of it she could receive a fixed benefit, which is lower than the benefit obtained during the first part. Only in Denmark is the benefit means-tested.

The low infant and motherhood mortality rates in Europe indicate effective maternal care. The mother is given physical examinations before and after childbirth. The child's health is examined, children are vaccinated and medical advice is given. Health care is provided free-of-charge or under the same conditions as other medical treatment.

The parents are also provided guidance in child welfare clinics in matters concerning child care. In many states guidance and counseling services have been start. ed in matters concerning family life, family planning and raising children as well as professional help, research and treatment in human relations. In addition to this, it is possible in many states to receive guidance in hereditary diseases and involuntary childlessness.

\section{Parental leave}

Parental leave means a leave which parents of the child can share with each other after the post-natal leave (maternity leave and paternity leave). In nine states (see Table 6) the father could use a part of the leave and be entitled to maternity benefit on full wage or salary. Parents have the right to freely decide how they will divide the leave between them. The length of this leave varies from one month to six months. Almost half of the states give the mother or both of the parents the cpportunity to continue the parental leave without benefit. The length of the unpaid leave varies from two years in Portugal to four weeks in Ireland.

The parental leave has been under discussion in some states, for example, in Austria, in the Netherlands and in the United Kingdom. In Belgium, parental leave is part of a more general regulation concerning the interruption of one's professional career.

Because it is not possible to take a sick child to the day-care center, parents are often faced with problems in arranging child care. In the Nordic countries, in the Federal Republic of Germany and in the Netherlands the mother or father may stay at home and take care of the sick child. This sick child's care leave is provided by law; in some states it is guaranteed in collective labor agreements.

\section{Child care services}

In most states child-care services are considered the responsibility of society, of state and local authorities. In all states various kinds of private child-care services are also available. 
It is not easy to get a good picture of the child-care situation and, for example, on the sufficiency and quality of services, to what extent working mothers manage to have their children in day care organized by the local authorities and to what degree they use private facilities, or whether services correspond to the parents ideas on how to bring up their children. In some states there are services for children below school-age, in some also for school-aged children.

It is obvious that the child-care systems are not developing at the same rate as the participation of mothers in the labor force is increasing. It is obvious, also, that there is a shortage of child-care facilities. In the Nordic countries, where the number of working mothers is high, the gaps between demand and supply are readily apparent. In the Netherlands, the supply of child-care services for children under 4 years is not sufficient. In the Federal Republic of Germany, 60 percent of all 3-4-yearold children and 90 percent of all 5 year-olds find room at nursery schools.

In the states, where there is a shortage of public child care services, children are accepted into child care, for example, in Belgium and Finland, according to the parents' income. In some states priority is given to single parents and in some to students, too. Families with problems often manage to get services more easily.

Mothers providing day care is the most common arrangement among the great variety of private child care services. In Switzerland 80 percent of day care for children from 2 months to 6 years of age is private. In Turkey employers who employ $100-300$ female workers have to provide a room in which mothers can feed and care for their children, and if the employer has more than 300 female employees, a day nursery has to be opened.

Child-care centers are not always open when parents are working. Especially shift and night workers may have problems getting child-care services.

\section{Family policy measures}

Young couples can be encouraged by family policy measures to set up a family. These measures support the economic and emotional development and well-being of the family. Measures which improve living conditions of individuals and families seem to have an effect on the possibilities on the couples to have as many children as they wish. Owing to the fact that societies have changed, the aims and methods of family policy have changed, too.

After World War II the contents of family policy started to take the form of making family-based costs more just. It is considered unfair that the living standard of a family with children is lower than that of a childless couple and singles. The economic position of a family with many children may be worse than that of a family with only one or two children.

In the 1970s the gainful employment of women with children started to become more common. The share of women aged 25 to 44 years has increased substantially (OECD 1988). That is why the trend was to carry on family policy which has taken this fact into account. The aim was to develop child-care services, especially. The aims of developing child care and making costs caused by a child more just are still essential points in many states in developing and reforming their family policy.

There are only a few explicit aspects of population policy stated in the family policy measures. This may seem strange, as worries about population development transpire from many opinions, conferences, articles and studies published in recent years. However, only Malta, the Netherlands and Turkey have stated explicit aims in their population policy. 
In the Netherlands, the official opinion is that a slowdown of population growth is a prerequisite for the welfare of the population. The target is a fertility rate of 15-30 percent below reproduction level. However, in the long run, the aim is a stationary population. Population is considered to be too dense also in Malta and slow population growth is aimed for, although no specific targets have been set up. Turkey has tried to lower its birth rate since 1960 .

In some states there has been open discussion about the lowering birth rate. The government of the Federal Republic of Germany is carefully observing the development of birth rates. However, parents have the right to decide how many children they want and when they want them. Family policy is said to be the main issue in federal government politics. In Cyprys one of the aims of the government is to improve the fertility rate. An additional benefit of 15 CYP per child is granted to persons who have more than three children. The Greek government has recently set up a special Committee on the Family and Population.

The report of the population committee (NOU 1984) set up by the government of Norway was published in 1984. When women aged 20-34 years were asked (1977) their ideal number of children, over half of them wanted two children and 40 percent three children. Most of the youngest and oldest respondents wanted three children. Of all the women only one percent wanted only one child or no children at all. When asked how many children they wanted to have the replies were centered on two or three children. The total fertility of Norway was 1.76 per women.

In order to increase the birth rate, the Norwegian committee considers that the starting point must be improving the situation and living conditions of families with children. However, achieving a society more favorable to children demands a redivision of resources and is such a large-scale operation that it requires a very long time, $10-12$ years. According to the Norwegian committee, attention should be paid to the following aspects in the program:

- Lengthening maternity leave up to one year and expanding parental rights so that they can stay away from work when their child is sick.

- Increasing the income transfers of families with children and a fixed child benefit. Together, they will increase the possibility for voluntary shortening of working time and would compensate for it.

- Building child-care centers to correspond to the full need.

- Building day care centers and/or lengthening the time spent in school for children from 7 to 9 years.

- Improving housing surroundings and neighborhoods into a more child-favorable direction.

Over the last decade, family policy in Europe has especially emphazised improvement of the situation of working parents and their children. In the United Kingdom, the integration of child-care services and gainful employment has especially been emphasised. In France, one of the aims of family policy is to facilitate child-care services for working parents. Cyprus is trying to increase the amount of working women and, therefore, is trying to create circumstances favorable for women to take part in social, political and economic life. Development of child-care services and arrangement of working hours is emphasized in the Nordic countries. There has been discussion about parental leave in the United Kingdom, too. In the Netherlands a bill is in preparation to introduce parental leave opportunities: as a right for every employee to take a part-time unpaid leave for six months after matenity leave (each parent separately).

In many states one target of a different family policy is to improve the well-being 
of all families with children and to develop support according to needs. Different kinds of measures have been taken, but child benefits exist in all states.

So far, family policy measures seem to have had no permanent influence on the number of children, some countries (France and Sweden) seem to have managed to slow down the fall in birth rates ${ }^{3}$. That is why research is aimed at clarifying the existing family policy measures, and finding out how supporting measures should be developed in the future.

Although it is important, because of social justice, to improve the livelihood of families with children, family policy measures, as they have been used, do not seem to have had more than a marginal effect on fertility. The number of children depends greatly also on other aims and values of life. It is essential to reconcile family life with employment and leisure time. It is obvious that, in the future, more attention has to be given to the arrangement of working hours as well as to childcare services.

As the economic welfare of families improves, more attention will be paid to the time parents and children can spend together. Denmark, the Federal Republic of Germany in Finland ${ }^{4}$ emphasize that mother and fathers should have enough time to bring up and take care of their children. The emphasis in the family policy of the Finnish Government is in improving the position of families with children. The child benefit system will be developed in such a way that the support will be improved and the age limit will be raised. ${ }^{5}$

As economic welfare rises, aspects of life other than financial ones are also beginning to gain in importance. Consequently, good social relations and hopes for children are considered to be a part of welfare and the aims people hold.

\section{References}

Anichkin, A.B. (1988). Demograficheskaya politika vo Frantsii (Demographic policy in France). Population Index 54 (3): 644.

NOU (1984). Befolkningsutviklingen. Norges offentlige utvecklinger. NOU 26. Oslo: Universitetsforlaget.

Ermisch, John (1987). Demographic aspects of the growing number of lone parent families. Paris. Unpublished paper.

Kamerman, Sheila B. and Kahn, Alfred J. (1989). Single-parent, female-headed families in Western Europe: social change and response. International Social Security Review 42 (1): 3-34.

OECD (1988). OECD Employment Outlook: September 1988. Paris: OECD.

${ }^{3}$ A.B. Anichkin estimates that the pronatalist measures adopted in France have increased the fertility rate by about 10 percent. Anichkin, A.B. Demograficheskaya politika vo Frantsij (Demographic policy in France). Sotsiologicheskie Issledovaniya, Vol. 14, No. 2, Mar-Apr 1987, pp. 74-82, Population Index, Vol. 54, No. 3, Fall 1988, p. 644.

${ }^{4}$ Dagens Nyheter, December 28, 1989: Födelsetal fortsätter att öka.

5 After August 1, 1988 Finnish parents with small children have had the right to a six- hour working day and to stay at home for four days at a time to care for a sick child. 
Table 1. Normal working hours and monthly wage.

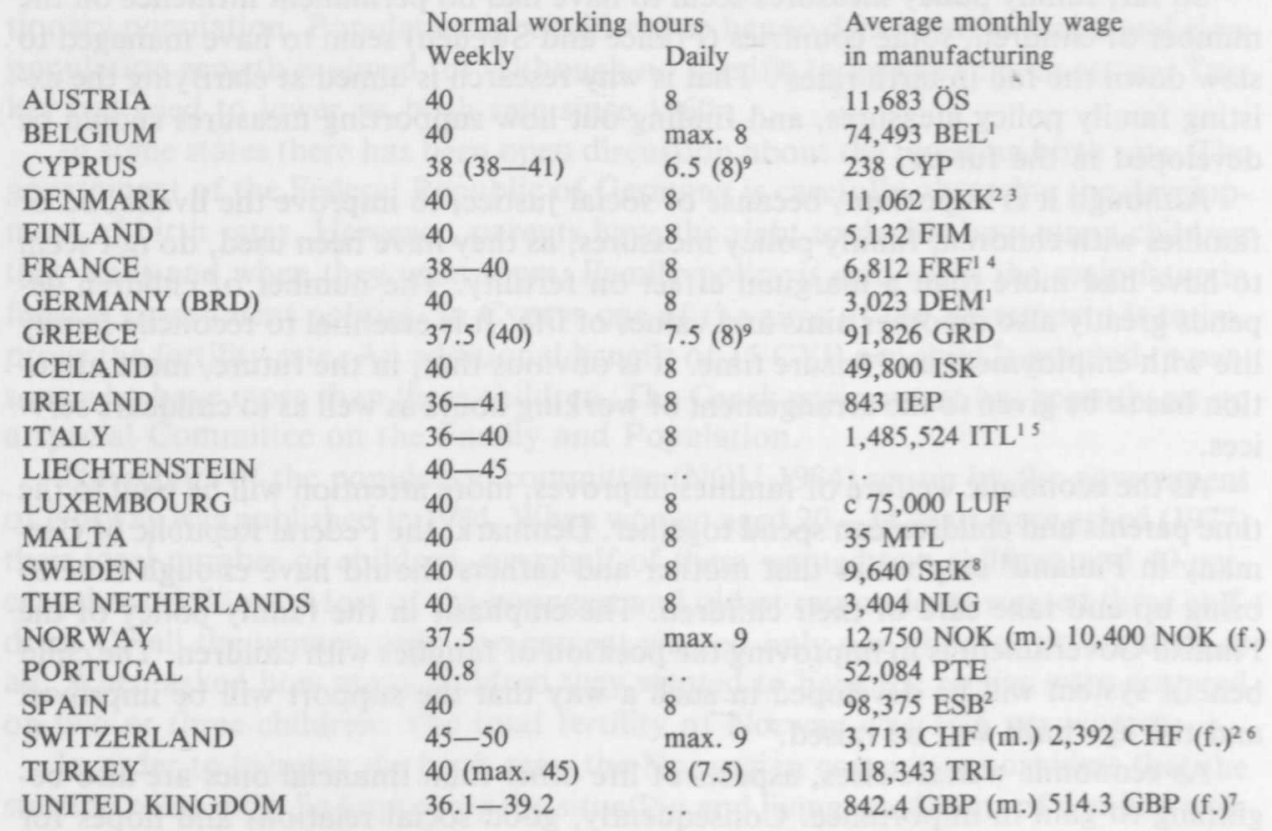

1 The information on wages and working hours is from the ILO Bulletin of Labour Statistics 1988-4, 1988. When information on monthly wage is lacking, the average monthly wage is approximated by multiplying the weekly wage by 4.3 .

2 The information on wages and working hours is from the ILO Yearbook of Labour Statistics 1987, 1987. When information on monthly wage is lacking, the average monthly wage is approximated by multiplying the weekly wage by 4.3 .

3 The average hours in manufacturing is the weighted mean of all manufacturing branches calculated from the ILO Yearbook 1987. The information is from 1986.

${ }^{4}$ Number of average hours of employees is from the ILO Bulletin 1988-4.

5 The weekly working hours are five times the daily working hours. The information is from 1985 .

6 The information is from 1986.

7 The information is from 1987.

${ }^{8}$ In Sweden a 6-hour-day is being planned.

9 The first number refers to the public sector, the second to the private. 
Table 2. Proportion of part-time employment by sex in the mid-1980s.

$\begin{array}{lccc} & \begin{array}{c}\text { All } \\ \text { persons }\end{array} & \begin{array}{c}\text { All } \\ \text { males }\end{array} & \begin{array}{c}\text { All } \\ \text { females }\end{array} \\ \text { Australia } & 20.0 & 7.4 & 39.2 \\ \text { Belgium } & 9.4 & 2.1 & 22.6 \\ \text { Canada } & 15.2 & 7.6 & 25.3 \\ \text { Denmark } & 23.7 & 8.7 & 41.9 \\ \text { Finland, 1986* } & 8.1 & 5.0 & 11.5 \\ \text { France } & 11.8 & 3.4 & 23.2 \\ \text { Germany } & 12.9 & 2.1 & 29.8 \\ \text { Greece } & 5.8 & 3.4 & 10.4 \\ \text { Ireland } & 6.2 & 2.5 & 14.2 \\ \text { Italy } & 5.0 & 2.8 & 9.5 \\ \text { Japan } & 16.6 & 7.3 & 30.5 \\ \text { Luxembourg } & 6.6 & 1.8 & 15.4 \\ \text { Netherlands } & 25.3 & 10.1 & 55.2 \\ \text { Norway } & 23.1 & 7.9 & 43.0 \\ \text { Portugal } & 6.0 & 3.4 & 10.0 \\ \text { Sweden } & 25.2 & 6.7 & 45.1 \\ \text { United Kingdom } & 21.6 & 4.6 & 45.0 \\ \text { United States } & 17.3 & 10.2 & 26.1\end{array}$

Source: OECD Employment Outlook: September 1988.

* Source: Ministry of Labour.

Table 3. The monthly share of the child benefits paid for two children as a percentage of average monthly wage in manufacturing in some states. (Calculated on the basis of Appendix 1 and Table 1).

State

Austria
Belgium
Cyprus
Denmark
Federal Repub
Finland
France
Greece
Iceland
Ireland
Italy
Liechtenstein
Luxembourg
Malta
The Netherland
Norway
Portugal
Spain
Sweden
Switzerland
Turkey
UK

Percent of average Notes monthly wage

22.7

8.3

3.6

5.0

7.8

10.1

\section{1}

$5.4-9.5$

3.6

2.6

7.4

17.7

1.3

9.7

4.8

0.5

10.1

$5.1-6.2$

3.5

7.4 one under, one over 10 years

one under 10 years, one aged $10-15$ years

one under 6 years, one $6-12$ years two children aged 6-11 years, males' wage

males' wage males' wage 
Table 4. Benefits paid at birth and during the child's first years in 1987.

\begin{tabular}{|c|c|}
\hline & \\
\hline Austria & $\begin{array}{l}\text { Birth grant of } 2,000 \text { ATS for each birth and of } 15,000 \text { ATS after medical examina- } \\
\text { tions. In four installments. }\end{array}$ \\
\hline Belgium & $\begin{array}{l}\text { Birth grant of } 29,484 \text { BEF for the first child and of } 20,335 \text { BEF for the second and } \\
\text { subsequent children. }\end{array}$ \\
\hline Finland & $\begin{array}{l}\text { Optionally } 610 \text { FIM or a package containing necessities for baby care, market value } \\
\text { about } 1,200 \text { FIM. Medical examination required. Home care benefit to families with } \\
2 \text { children under } 7 \text { years and one under } 3 \text { years or } 1 \text { child under } 20 \text { months. }\end{array}$ \\
\hline France & $\begin{array}{l}\text { Special benefit for } 9 \text { months to families where both parents are gainfully employed } \\
\text { or one takes care of the child at home (low-income families } 32 \text { months). Medical } \\
\text { examination required. }\end{array}$ \\
\hline $\begin{array}{l}\text { Federal } \\
\text { Republic of } \\
\text { Germany }\end{array}$ & $\begin{array}{l}\text { Up to one year, } 600 \text { DEM for } 6 \text { months irrespective of income. After that means- } \\
\text { tested. No medical examination required. }\end{array}$ \\
\hline Greece & For each delivery 40,000 GRD in public sector and 62,000 GRD in private sector. \\
\hline Liechtenstein & 750 CHF. $300-1,500 \mathrm{CHF}$, means-tested. No medical examination. \\
\hline Luxembourg & $\begin{array}{l}\text { Prenatal benefit of } 15,380 \text { LUF after five medical examinations, birth grant of } 15,380 \\
\text { LUF, post-natal benefit of } 15,380 \text { LUF, and maternity benefit of } 3,429 \text { per week for } \\
16 \text { weeks. }\end{array}$ \\
\hline Portugal & $\begin{array}{l}13,350 \text { PTE to working mothers. For the first } 10 \text { months a nursing benefit of } 2,450 \\
\text { PTE per month. No medical examination. }\end{array}$ \\
\hline Turkey & $\begin{array}{l}\text { Pregnant women's medical expenses paid. Special breast-feeding benefit and disability } \\
\text { grant for pregnant women. }\end{array}$ \\
\hline me & 85 GBP (means-tested). No medical examination. \\
\hline
\end{tabular}

Table 5. Length of paid and unpaid pregnancy leave, length of leave prior to estimated date of birth, paternal leave, 1987.

\begin{tabular}{|c|c|c|c|c|}
\hline & $\begin{array}{l}\text { Length of leave } \\
\text { paid }\end{array}$ & Unpaid & $\begin{array}{l}\text { Prior to } \\
\text { estimated } \\
\text { date of birth }\end{array}$ & $\begin{array}{l}\text { Father has } \\
\text { right to } \\
\text { paid leave } \\
\text { at birth }\end{array}$ \\
\hline AUSTRIA & 60 weeks & no & 42 days & no \\
\hline BELGIUM & 8 weeks & no & - & no \\
\hline CYPRUS & 84 days & no & 14 days & no \\
\hline DENMARK & 28 weeks & no & 4 weeks & 2 weeks \\
\hline GERMANY (BRD) & 14 weeks & no & 6 weeks & no \\
\hline FINLAND & 258 days & 1 year & 25 days & 12 days \\
\hline FRANCE & - & - & - & - \\
\hline GREECE & 120 days & $75-90$ days & 60 days & no (1) \\
\hline ICELAND & 3 months & no & - & no \\
\hline IRELAND & 14 weeks & 4 weeks & $4-10$ weeks & no \\
\hline ITALY & 11 months & no & 2 months & no \\
\hline LIECHTENSTEIN & - & - & 2 months & no \\
\hline LUXEMBOURG & $120-150$ days & 365 days & 60 days & no \\
\hline MALTA & 13 weeks & no (1) & 2 days & 3 days \\
\hline THE NETHERLANDS & $\begin{array}{l}12 \text { weeks } \\
\text { civil servants, } \\
\text { employees }\end{array}$ & no (2) & $2-6$ weeks & no \\
\hline NORWAY & $\begin{array}{l}110 \\
\text { workdays }\end{array}$ & $\begin{array}{l}\text { until the } \\
\text { child is } \\
\text { one year old }\end{array}$ & $\begin{array}{l}\max 60 \\
\text { workdays }\end{array}$ & no (2) \\
\hline PORTUGAL & 90 days & 2 years & 30 days & no \\
\hline
\end{tabular}




\begin{tabular}{|c|c|c|c|c|}
\hline SPAIN & 90 days & no & 30 days & no \\
\hline SWEDEN & 360 days & 180 days & 60 days & 10 days \\
\hline SWITZERLAND & employed & no & no & no \\
\hline & $\begin{array}{l}3 \text { weeks to } \\
2 \text { months, } \\
\text { up to } 4 \text { mo. }\end{array}$ & & & 0 1 0 \\
\hline TURKEY & $\begin{array}{l}\text { civil servants } \\
5 \text { weeks, } \\
\text { workers } 12 \text { wk. }\end{array}$ & 6 months & $\begin{array}{l}\text { civil servants } \\
3 \text { weeks, } \\
\text { workers } 6 \text { wk. }\end{array}$ & 3 days \\
\hline UK & max. 126 days & $\max .77$ days & $\begin{array}{l}\text { min. } 77 \text { days } \\
\text { depends on } \\
\text { length of } \\
\text { paid leave }\end{array}$ & no \\
\hline
\end{tabular}

(1) Mothers employed by the government and by some banking organization have the right to unpaid leave up to one year.

(2) A bill is in preparation to introduce the right for every employee to take part-time unpaid leave for 6 months.

Table 6. Maternity benefits and parental leave, 1987.

\begin{tabular}{|c|c|c|}
\hline & $\begin{array}{l}\text { Maternity benefit as a } \\
\text { percent of wage or salary }\end{array}$ & $\begin{array}{l}\text { Either of parents is } \\
\text { entitled to use the } \\
\text { leave or part of it }\end{array}$ \\
\hline AUSTRIA & $\begin{array}{l}16 \text { weeks full wage or salary } \\
\text { fixed benefit for } 10 \text { months }\end{array}$ & no \\
\hline BELGIUM & wage or salary or $60 \%$ & $6-12$ months after the leave \\
\hline CYPRUS & about $75 \%$ & no \\
\hline DENMARK & means-tested & 10 weeks \\
\hline GERMANY (BRD) & $\begin{array}{l}\text { varies according to } \\
\text { insurance system }\end{array}$ & 12 months \\
\hline FINLAND & $80 \%$ & 158 days \\
\hline FRANCE & - & - \\
\hline GREECE & (wage or salary) & $75-90$ days \\
\hline ICELAND & $\begin{array}{l}\text { employees } 100 \% \text {, others fixed } \\
\text { allowance }\end{array}$ & 1 month \\
\hline IRELAND & $70 \%$ & no \\
\hline ITALY & $\begin{array}{l}5 \text { months } 80 \%, 6 \text { months } 30 \% \\
\text { of normal earnings }\end{array}$ & $\begin{array}{l}6 \text { months after } \\
\text { the pregnancy }\end{array}$ \\
\hline LIECHTENSTEIN & - & no \\
\hline LUXEMBOURG & mostly normal salary & no \\
\hline MALTA & (wage or salary) & no \\
\hline THE NETHERLANDS & $100 \%$ & no \\
\hline NORWAY & $100 \%$ & 70 workdays \\
\hline PORTUGAL & civil servants $100 \%$, others varying & no \\
\hline SPAIN & - & no \\
\hline SWEDEN & $\begin{array}{l}90 \% \text { for } 270 \text { days, fixed } \\
\text { benefit for next } 90 \text { days ( } 60 \text { SEK) }\end{array}$ & 180 days \\
\hline SWITZERLAND & wage or salary & no \\
\hline TURKEY & (wage or salary) & no \\
\hline JK & $\begin{array}{l}\max 90 \% \text { of average wage for } 42 \\
\text { days, fixed benefit for next } 84 \\
\text { days (GBP } 25-34 / \text { week) }\end{array}$ & no \\
\hline
\end{tabular}


Appendix 1. Child benefits and other benefits.

\begin{tabular}{|c|c|c|}
\hline AUSTRIA & $\begin{array}{l}\text { Under } 10 \text { years } 14,000 \text { ATS, over } 10 \text { years } 1 \\
\text { Extended to age } 25-27 \text { in special cases. Age }\end{array}$ & $\begin{array}{l}400 \text { ATS. } \\
\text { of expiry } 19 .\end{array}$ \\
\hline BELGIUM & $\begin{array}{l}\text { Increases with order of child: the employed } \\
\begin{array}{l}\text { 1st child } \\
\text { 2nd child }\end{array} \\
\text { 3rd and subsequent child } 724 \mathrm{BEF} \\
72,144 \mathrm{BEF} \\
\end{array}$ & $\begin{array}{c}\text { the unemployed } \\
37,236 \mathrm{BEF} \\
55,476 \mathrm{BEF} \\
72,144 \mathrm{BEF}\end{array}$ \\
\hline
\end{tabular}

Age-based increments: $6-12$ years $7,236 \mathrm{BEF}, 12-16$ years $11,436 \mathrm{BEF}, 16+$ years 16,284 BEF. Age of expiry 16-18. Several benefit systems where the benefit increases according to age and number of children. Extended in special cases to age 25. Exempted from taxation, not means-tested.

CYPRUS Benefit of $84 \mathrm{CYP} /$ child is paid only to families with four or more children. Age of expiry 18 . Extended to age 25 for a male if being educated or in military service, for a female student to age 23. Exempted from taxation, not means-tested.

DENMARK

FINLAND

FRANCE

FEDERAL

REPUBLIC OF

GERMANY

GREECE

ICELAND

IRELAND
5,000 DKK per child. Age of expiry 18. Exempted from taxation, not means-tested.

$\begin{array}{llll}\text { 1st child } & \text { 2,616 FIM } & \text { 4th child } & \text { 5,096 FIM } \\ \text { 2nd child } & \text { 3,032 FIM } & \text { 5th and subsequent } \\ \text { 3rd child } & 3,916 \text { FIM } & \text { child }\end{array}$

For children under 3 increased by 1,284 FIM per child. Age of expiry 17. Housing subsidy for low-income families. Graded in several ways. Exempted from taxation, not means-tested.

2 children 6,702 FRF 4 children 23,877 FRF

3 children 15,290 FRF for each subsequent child 8,587 FRF

Age of expiry 16. Exempted from taxation, not means-tested. A supplement of 1,885 FRF is paid for children aged $10-15$ and 3,351 FRF for those over 15. Extended in special cases to age 20 . Means-tested family income supplement of 8,724 FRF per year for a household with at least three dependent children over 3 . A school expense benefit is paid to low-income families with school children.

A housing benefit graded in several ways for housing costs. A parent who takes care of a child under 3 at home is entitled to a benefit up to 24,000 FRF (in parttime work 12,000 FRF).

$\begin{array}{ll}\text { 1st child } 600 \mathrm{DEM} & \text { 3rd child 2,640 DEM } \\ \text { 2nd child 1,200 DEM } & \text { 4th child 2,880 DEM }\end{array}$

2nd child 1,200 DEM 4th child 2,880 DEM

Exempted from taxation, means-tested. Age of expiry 16. Extended in special cases to age 27 . For high-income families, the benefit is reduced for the second and subsequent child.

A housing benefit graded according to income, number of children and housing costs to compensate for housing costs. Housing benefit is at max. 34,320 DEM for a family with two children and 43,680 DEM for a family with four children.

Varies according to income and order of the child:

1 st child 11,040 - 7,500 GRD 3rd child 83,040-44,640 GRD

2nd child 38,040-30,000 GRD 4th child 96,000-64,000 GRD

Age of expiry 18. No exemption from taxation.

Varies according to age: under 7 years over 7 years
1st child
25,250 ISK
12,625 ISK
2nd child
31,535 ISK
19,910 ISK

In one-parent family the benefit is 33,600 ISK per child. Age of expiry 16. Exempted from taxation, not means-tested. The benefit is granted as a deduction from state taxes. A supplementary benefit of 25,250 ISK is granted to low-income families.

1st-5th child 180.6 IEP 6th-child 261.0 IEP

Age of expiry 16. Extended to 18 years if the child is in full-time education or handicapped.

Special benefit for a single provider: for the 1 st child $57.80 /$ month, an additional $12.70 /$ month for the 2 nd to 5 th child and $10.90 /$ month for the 6 th and each subsequent child. Age of expiry 18. If the child is being educated full-time, 21 years. Exempted from taxation, not means-tested. 
Annual amount

ITALY

LIECHTENSTEIN

LUXEMBOURG

MALTA

THE

NETHERLANDS

NORWAY

PORTUGAL

SPAIN

SWEDEN

SWITZERLAND
Varies depending on income and number of children:

1 child $180,000-540,000$ ITL

2 children $180,000-1,080,000$ ITL

3 children $180,000-1,620,000$ ITL

4 children $648,000-2,160,000$ ITL

Supplementary benefit of 237,120 ITL is granted for low-income families for each child. Age of expiry 18.

Exempted from taxation, not means-tested.

$1-2$ children $\quad 1,400 \mathrm{CHF}$ per child

3 or more children $1,800 \mathrm{CHF}$ per child.

Augmented at age of 10 with 1,800 CHF. Age of expiry 18. Exempted from taxation, not means-tested.

1 child 21,084 LUF 3 children 141,456 LUF

2 children 64,296 LUF

For each subsequent child an additional payment of 63,276 LUF per child. Augmented at age 6 with 2,100 LUF, at age 12 with 6,888 LUF. Age of expiry 18. Extended to age 25, if the child is being educated. Exempted from taxation, not means-tested.

1st child 182.0 MTP 3rd child 88.4 MTP

2nd child 140.4 MTP 4th and subsequent child 15.6 MTP

Age of expiry 16.

Varies according to age and number of children:

1 child 212.3-394.9 DFL

20 children $453.6-842.5$ DFL

Age of expiry 17. Exempted from taxation, not means-tested. Special arragements for students aged 18-27. Means-tested special benefit for a single provider.

1st child 7,188 NOK 4th child 9,720 NOK

2nd child 7,680 NOK 5th child 10,104 NOK

3rd child 9,096 NOK 6th child 10,104 NOK

Age of expiry 16. Single providers are given benefit for one child more than the actual child. Exempted from taxation, not means-tested.

15,000 PTE per child for low-income families, i.e. less than $1 \frac{1}{2}$ times the minimum wage. 22,560 PTE per fourth and subsequent child. Exempted from taxation, means-tested. Age of expiry 18 . Extended to age 22-25, if child is being educated. A supplementary benefit of 3,150-6,190 PTE, graded by age, is granted to handicapped children to age 24 .

1st to 3rd child 3,000 ESP 7th to 9th child 3,900 ESP

4 th to 6 th child 3,750 ESP 10th and subsequent 4,050 ESP

Age of expiry 15. Exempted from taxation, not means-tested. A supplementary benefit of 1,050 ESP for low-income families.

5,820 SEK per child. A supplementary benefit is paid to families with 3 or more children: 3 rd child 2,910 SEK, 4 th child 5,820 SEK. No exemption from taxation, not means-tested. Age of expiry 16. Students in secondary school aged 16-20 enjoy an allowance of 5,820 SEK per year.

A supplementary means-tested housing subsidy, max. 3,180 SEK/child. Maintenance support of 10,320 SEK/year/child for children who cannot get sufficient maintenance from the parent who does not have custody. Age of expiry 18 .

Small self-employed farmers (income limit) and agricultural workers receive a benefit according to federal scheme: 1,140-1,150 CHF/child. Employees according to cantonal schemes: $960-1,740 \mathrm{CHF} /$ child, for $3 \mathrm{rd}$ and subsequent child up to 2,028 $\mathrm{CHF} /$ child. Age of expiry $15-18$. Extended to age $20-25$ for the handicapped and students. No exemption from taxation, means-tested. 
Annual amount

TURKEY

Benefit is granted for civil servants only and varies depending on the age of the child and his/her education:

under school age 1,800 TP in secondary school 7,200 TP

in primary school $2,400 \mathrm{TP}$ in higher education 10,800 TP

A supplement of 11,040 TP for a non-employed spouse. Age of expiry 19. Extended to age 25 for unmarried girls and for boys in higher education. Not meanstested.

UNITED

KINGDOM
377 GBP for each child. Age of expiry 15. Extended to age 19 if the child is being provided full-time non-advanced education. An additional one-parent benefit of 4.90 GBP/week/family is provided. Exempted from taxation, not means-tested.

\section{Appendix 2. Tax deductions.}

Only those tax deductions which exist in each state in question are mentioned. The information on 15 states is based on the replies of the second questionnaire, the rest (marked by ${ }^{*}$ ) on the replies of the first questionnaire.

\section{AUSTRIA}

Child-care costs

Housing deductions

Age of expiry

Deductions for

educational costs

Deductions for

single providers

BELGIUM $(*)$

Normal deduction

Housing deductions

Deductions for

single providers

CYPRUS

Normal deduction

Child-care costs

Housing deductions if both parents are working 10,000 ATS

if only one parent is working 20,000 ATS

10,000 ATS $+5,000$ ATS per child for interest, building costs and amortization

19

yes

47,400 ATS per year

Increases with number of children

1 child $\quad 7,5 \% 7,200-8,000 \mathrm{BEF}$

6 children $95,0 \%$ 153,700-198,000 BEF

$6+\quad 198,000 \mathrm{BEF}+54,000 \mathrm{BEF}$ per child

An additional deduction of $20 \%$ (max. 125,000) to newly-wed couples in his/her first marriage in the first year and also in the following one if a child is born.

$10 \%$ property tax deduction for each dependent child, providing that the family has at least 2 children.

$5 \%$ deduction for interest in some cases deductions for amortization

\section{4,618 BEF}

child under $16 \quad 250$ CYP from taxable income

at secondary school $300 \mathrm{CYP}$

at high school $\quad 500 \mathrm{CYP}$

$16-28$ in full-time education

at college or university $\quad 1,000$ CYP

in national guard $300 \mathrm{CYP}$

+15 CYP deduction from tax per child if more than 3 children

250 CYP for working mothers with a child under 5 years

max. 1,200 CYP deduction from taxable income for interest on housing loans 
FINLAND

Normal deduction

Child-care costs

Age of expiry

Housing deductions

Deductions for

educational costs

Age

Deductions for

single providers

FRANCE (*)

Normal deduction

Child-care costs

Age of expiry

Housing deductions

Deductions for educational costs

Deductions for

single providers
Increases with number of children

1 child 3,970 FIM

:

5 children 18,390 FIM $+6,090$ FIM for each subsequent child

$20 \%$ of total income max. 7,000 FIM

(max. 12,000 FIM if the child is 7 or younger)

18

max. 25,000 FIM deduction for interest on loan

\section{1,800 FIM \\ 16-18}

\section{8,700 FIM}

Taxable income is divided into shares (parent 1 , child $1 / 2$ ) in order to lower income, max. deduction per half-share 9,960 FRF, extra half-share after 3rd child.

up to 10,000 FRF per child

6

max. 15,000 FRF for one-parent family and 30,000 FRF for a married couple; increment for each child

Study grants are exempted from taxation

extra half-share after 1st child

FEDERAL REPUBLIC OF GERMANY

Normal deduction

Child-care cost's

Housing deductions

Deductions for educational costs

Age

Deductions for

single providers

\section{GREECE}

Normal deduction

Housing deductions

Deductions for

educational costs

Deductions for

single providers

ICELAND

Normal deduction

Deductions for

educational costs

Age

Deductions for

single providers

IRELAND

Normal deduction

Housing deductions

Deductions for

educational costs

Deductions for

single providers
2,484 DEM per child (payment up to 46 DEM for those who don't profit from the tax deduction because of lack of income)

yes

$5 \%$ up to 300,000 DEM deduction for aquisition costs during the first 8 years +600 DEM for every child

\begin{tabular}{lll}
\multicolumn{2}{c}{ not at home } & at home \\
1,200 DEM & 4,200 DEM & 2,400 DEM \\
over 18 & under 18 & under 18
\end{tabular}

752 DEM

Increases with order of child

1st child 14,000 GRD

5th and subsequent child 80,000 GRD

$4 \%$ on loans for amortization

$4 \%$ of costs up to 20,000 GRD per child

at the birth of the child 10,000 GRD

$10 \%$ from gross income

for large expenses

under 16

Single parent 112,455 ISK

Unmarried 64,260 ISK

no

deduction for $90 \%$ of interest on loans

income from a grant up to 3,000 IEP

2,000 IEP for a divorced or a single provider 
ITALY (*)

Normal deductions

Deductions for educational costs

Age

LUXEMBOURG

Normal deduction

Child-care costs

Housing deductions

MALTA

Normal deduction

Child-care cost

Housing deductions

Deductions for

single providers

THE NETHERLANDS

Normal deduction

Deductions for

educational costs

Deductions for

single providers

NORWAY

Normal deduction

Child-care costs

Deductions for

single providers

PORTUGAL

Normal deduction

Age of expiry

Housing deductions

Deduction for

educational costs

SPAIN

Normal deduction

Housing deductions

\section{SWEDEN}

Normal deduction Housing deductions

SWITZERLAND (*)

Normal deduction
Varies according to the number of children but fixed after 4th child; if wife has no income, husband is granted an additional deduction.

yes

26

Deduction varies $3-7 \%$ from taxable income in families with one or two children, and $1-5 \%$ in families with three or more children; the higher the income, the higher the percentage.

if both parents are working

Loan interest up to 20,000 LUF, limit raised by 20,000 LUF for the spouse and also 20,000 LUF for each child.

under 9 years 130 MTP

9-16 years 145 MTP

$17-21$ years $160 \mathrm{MTP}$

max. 500 MTP

deduction for interest paid up to rental value of residence

deduction for payment for services of maids

no (from January 1, 1988)

educational grants

5,873 NLG

Income deduction:

1 child under 14 years 3,500 NOK

2 or more under 14 years 4,500 NOK

$$
\text { 14-19 years } 600 \text { NOK }
$$

tax deduction:

each child under 16 years 1,820 NOK

16-18 years 2,540 NOK

For care of handicapped child deduction from income up to $12,000 \mathrm{NOK}$ for one child, 14,500 NOK for two or more children. Expenses must be documented.

Children aged 16-18 are granted deduction for one child more than actual number.

over 11 years 50,000 PTE

under 11 years 70,000 PTE

18-24 years, non-subsidised unemployed child living in parental home families with 5 or more children have a minimum of 350,000 PTE tax rebate

24 , provided that the child is a student

180,000 PTE deduction for interest (including deductions for educational costs)

up to 70,000 PTE per child under age 24

18,000 ESP for each child

up to 800,000 ESP deduction for interest $17 \%$ of investment costs for building costs

$\max 1,800$ SEK for those with children under 18

deduction for interest: up to about $50 \%$ of the value

varies from canton to canton $1,600-3,700 \mathrm{SF}$ 
TURKEY

Normal deduction

Child-care costs

Deductions for

educational costs

Age

UNITED KINGDOM

Normal deduction

Housing deductions

Deduction for

single providers no

upbringing and educational costs if documented

educational or training costs if documented

no age limit

no

relief for interest on loans up to $30,000 \mathrm{GBP}$

$1,490 \mathrm{GBP}$ in addition to basic 2,605 GBP allowance for single persons.

Child's age under 18. Children aged $16-18$ must be attending full-time education or training. 